\title{
Meaning and Language
}

\author{
Jesus Martinez del Castillo \\ Department of Philology, Faculty of Economy and Tourism, Universidad de Almería, Almería, Spain
}

Email address:

jesus.gerardo@ual.es, apofansis@msn.com

\section{To cite this article:}

Jesus Martinez del Castillo. Meaning and Language. International Journal of Language and Linguistics. Special Issue: Linguistics of Saying. Vol. 3, No. 6-1, 2015, pp. 50-58. doi: 10.11648/j.ijll.s.2015030601.17

\begin{abstract}
Meaning defines language because it is the internal function of language. At the same time, meaning does not exist unless in language and because of language. From the point of view of the speaking subject meaning is contents of conscience. From the point of view of a language, meaning is the objectification of knowledge in linguistic signs. And from the point of view of the individual speaking subject, meaning is the expressive intentional purpose to say something.
\end{abstract}

Keywords: Language, A Language, Contents of Conscience, Designation, Meaning, Sense, The Speaking Subject, The Speech Community

\section{The Role of Meaning in Language}

Meaning is something particularly problematic. Meaning defines language since it is in direct connection with the very existence of language. Language is nothing but the creation of meanings ${ }^{1}$. Meaning thus is universal and necessary for language to exist. At the same time meaning manifests itself in language. In this sense meaning is real. It manifests itself in the words and expressions of a language. It is diverse, that is, multifarious and multiple. Because of this, meaning is something belonging to a particular language, something historical, that is, made in a speech community in history. Real meaning exists only in speech acts. Under this perspective meaning manifests itself as sense.

In the first aspect, meaning is the defining internal and original function of language ${ }^{2}$. It is nothing but contents of conscience $^{3}$, something created when language is created, that is, when language is spoken. Language exists because the speaking subject aims at saying something in the circumstance he is in $^{4}$. In the second aspect, meaning is something objective, or rather, objectified, belonging to a particular language, something offered to speakers from the tradition in the technique of speaking. Because of this meaning is common $^{5}$

1 Coseriu 1985a: 26

2 Cf. Coseriu 1985a, p. 46.

3 Coseriu 1985a: 27

4 Cf. Ortega y Gasset, 1992, pp. 46-47.

5 Cf. Coseriu 1988, p. 70. and participated ${ }^{6}$ in a particular speech community and thus contingent but virtual $7^{7}$.

Meaning constitutes the primary function of language, that is, to mean. Language is determined and thus defined by its meaningful function, its internal determination: creating meanings. In this sense, language is autonomous ${ }^{8}$ since it has an internal determination.

In the third aspect, meaning manifests itself a sporadic, contextual and individual. Since language is real, something lived by speakers ${ }^{9}$, meaning appears in contexts and situations, that is, meaning is sense.

\section{Meaning and Language Use}

The primary function of language, the creation of meanings, must not be confused with language use. Language is used for specific external purposes, the most important of which is communication. Because of this language is instrumental10. But language cannot be identified with the use made of it. Language is to be defined by its primary function, its internal determination. The use of language constitutes the external determination of language. Language cannot be defined by its external determinations but its internal determination. Language defines itself because of meaning and thus both

6 Cf. Coseriu 1988, 43.

7 Cf. Coseriu 1982, p. 296.

8 Coseriu 1985a, pp. 23-33.

9 Cf. Martínez del Castillo 2013.

10 Cf. Coseriu 1985a, p. 38. 
language and meaning are autonomous $11 \mathrm{but}$ not instrumental. This means that language primarily is something coming to speakers from their inside12. Human subjects speak because they have something to say; they say because they know13. Knowing and saying thus are internal functions of human subjects, who live in a circumstance ${ }^{14}$. Since human subjects form society with language, language manifests itself as a language 15. Languages form different social institutions, something coming to individual subjects from their outside16.

As a consequence, language properly speaking is not expression with meaning. Expression certainly exists in language, but language is primarily meaning and not the other way round. In this sense, according to Coseriu, you'd rather say language is meaning with expression 17.

And in dealing with the meaningful function of language or the internal determination of it, language must be understood

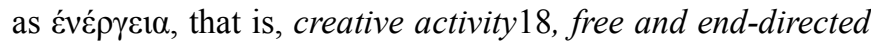
activity19. Language is not use but the creation of meanings.

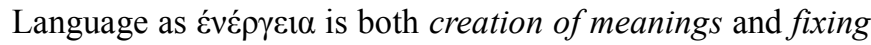
those meanings. The objectification of knowledge 20 is given in linguistic signs. Now then, 'to know' means conceiving of something as identical with itself and different from all other things. But that thing conceived of as identical with itself and different from all other things is nothing but contents of conscience, that is, meanings 21 . And in this you have the reason for language to exist: meaning is nothing but the internal function of language, something in connection with knowledge. Language is nothing but cognizant activity 22.

In this way language is the union of intuition and expression 23. It is the creation of meanings and signs to express those meanings. Because of this you can ask whether language is absolute or if language is only a language. Language has two dimensions. Language, first, it is the formulation or execution of an intuition. It is the relation of an absolute subject and his creation. In this sense language is absolute, that is, has no limits in creating meanings. And language is, second, the execution of the relation established between two speaking subjects. The first dimension is the relation subject-object, the execution of an intuition on the part of the speaker in words of a language. The second is the relation subject-subject: the creative subject of language presupposes other subjects with whom he has something in common. In this sense language is historical, that is, made in a speech community in history. The first dimension of language

\footnotetext{
11 Coseriu 1985a, pp. 23-33.

12 Cf. Ortega y Gasset 2001, p. 259.

13 Cf. Martínez del Castillo, 2004.

14 Ortega y Gasset 1994, p. 190.

15 Cf. Coseriu 1985a, p. 48.

16 Cf. Ortega y Gasset 2001, p. 259.

17 Coseriu 1985a, p. 38

18 Coseriu 1985a, p. 23.

19 Coseriu 1988, p. 249

20 Coseriu 1985a, p. 27.

21 Coseriu 1985a, p. 27.

22 Coseriu 1985a, p. 42.

23 Coseriu 1985a, p. 30.
}

is creation, the second dimension, otherness 24 , that is, speaking to others. Language is intended to others.

Language always manifests as a language 25 , a historical language, that is, a particular language having been made in a speech community in history. Language thus is the apprehension of being26, that is, apprehension not of things but the apprehension of that aspect making the thing perceived to be a thing. In this sense language is the delimitation of species 27 , that is, something is made to be a particular thing because of language. This apprehension of things is not by an absolute subject but a historical subject, who insofar as it is historical it is at the same time social28.

In this sense language is $\lambda$ óyo $\zeta$, that is, both the creation of Being (the class of things, the category) by an absolute subject, and intersubjective $\lambda$ ó$_{\gamma} \mathrm{s}$, that is, form and expression of the historicity of Man29. Human beings live in a linguistic world created by them as historical subjects (subjects who made themselves in participation with others in a speech community in history). Language relates to the first dimension, the dimension of human subjects and Being (Man and Being). Language as a language relates to the relation of human subjects to other human subjects, who by means of language, are attributed humanity, that is, the capacity of asking for Being and interpreting it, the capacity of asking for things and entities thus interpreting them 30 .

This apprehension of Being, manifests itself as contents of conscience and historical meanings.

\section{Speech Acts}

Language is activity, the activity of speaking 31 , consisting in a set of mental operations executed with the purpose of "saying something about something with the help of the signs of a particular language" 32 . Language does not exist in itself. It does not have concrete existence. It merely exists as the performance of that activity. Language exists in the series of speech acts performed by speakers33. A speech act is the performance of language on the part of the speaker. Speech acts have concrete existence thus representing the manifestation of language, both in itself and in its historical form.

\footnotetext{
24 Coseriu 1985a, p. 31.

25 Coseriu 1985a, p. 16.

26 Coseriu 1985a, p. 32.

27 "l... language does not certainly create natural "things" or entities, or in other words, objective things, thus attributing them a particular way of being [...] nor does it create being usually attributed to "things": on the contrary, it acknowledges and delimits modalities of being in things. Because of this language is delimitation of species or [...] "classes" of things (classes which, [...] from the point of view of its being objectified, can be as well classes of only one member or even empty classes)" (Coseriu 2006, pp. 73-74) (my translation).

28 Cf. Coseriu 1985a, p. 32.

29 Coseriu 1985 , p. 32.

30 Cf. Coseriu 1985a, 32-33.

31 Coseriu 1988, p. 249.

32 Coseriu 1982, p. 291.

33 Coseriu 1988, p. 45
} 
A speech act has to do with the act of apprehending things, that is, knowledge. A speech act is the manifestation of a unique intuition on the part of the speaker34. In this sense speech acts are determined with the meaningful intentional purpose of speakers. Speakers speak because they have something to say and they say because they are able to know. Speech acts, thus, are acts of knowing, saying and speaking35.

Language exists as the creation of meanings and as such language is at the same time and because of it the creation of knowledge 36. On the other hand a language exists as a sketch, model, draft, form or a pattern of an activity37. A language exists virtually because it is knowledge, the knowledge of speakers to speak, that is, idiomatic knowledge38.

The only thing really existing with concrete existence 39 is speech acts, innumerable speech acts. Anything in language is in speech acts. Speech acts display what language and a language are, something being executed in a single act, determined with the meaningful expressive intention of the individual speaker40.

The purpose of language, to mean, to create meanings, to say something about something with the means of a language, is performed in speech acts. The purpose of a language, speaking with someone else, is performed by means of words, linguistic concepts associated with linguistic signs. The function of speech acts is to use those words and concepts in such a way that they can refer to things in the world. Since idiomatic knowledge is virtual, linguistic signs refer not to objects but classes of objects. It is necessary then to orientate linguistics signs to real things. And this is performed in speech acts by means of determination, something to be performed with the means of expression of a particular language thus referring them to contexts and situations 41 .

The function of speech acts is to apply virtual concepts to real things. Concepts are universal and virtual, able to be applied of individual objects thus predicating the essential characteristics they potentially denote. Speech acts thus represent an act of transformation of abstract concepts, applicable only to the essence of things, into concrete expressions of meaning with designation in real things. Speech acts are thus the creation of sense, the creation of concrete forms of the activity of speaking, that is, the creation of language or the performance of language.

\section{Meaning and Speech}

Speakers will always speak of something (designation), using the elements of a language (historical means, that is,

\footnotetext{
34 Coseriu 1986a, pp. 27-28.

35 Cf. Martínez del Castillo, 2004.

36 Coseriu 1985, p. 26-27.

37 Coseriu 1988, p. 48.

38 Coseriu 1982, p. 313

39 Coseriu 1985, p. 87.

40 Cf. Martínez del Castillo, 2004; cf. a summary of the theory saying in Martínez

del Castillo, 2013, § 12 .

41 Cf. Coseriu 1982, pp. 290-319.
}

meanings). They will say something with the help of designation and (historical) meanings, thus creating sense. Speakers create sense whenever they speak. In this sense speakers bear in mind who they direct their speech to (the listener, the "you") and what are the circumstances affecting their speech (contexts and situations). Bearing this in mind, speakers select the elements more suitable to their needs of expression. The result is a series of speech acts that in so far as they are performed can be studied and analysed as texts.

In a text, that is, in the individual performance of language, language can be used at two levels:

a) the level of denotation, or

b) the level of connotation.

An expression is at the denotative level when it means the usual meaning given in a particular language. For example, green means colour and in this sense you can say

\section{grass is green; the green grass. It appears green}

But sometimes a particular word may get certain clues and shades of meaning not belonging to the meaning of the word but to language use, under certain circumstances. In this case we speak of connotation (or connotative level). So connotative meaning is not the meaning belonging to the language but to certain uses associated with the meaning of the word usually created in a particular group of people. You can see the difference between denotation and connotation in the following examples,

A green tree; green leaves; get him eat freshly potatoes and greens; the green fruits were as hard as rocks 42.

\section{in contrast with}

I'm waiting the green light from you; the minister gave the green light to the project 43 .

The examples in the first group denote, that is, they convey the traditional meaning, the usual meaning of a language. The examples in the second group, however, represent senses that once were individual or metaphorical. Then they were inserted in the tradition of the language as extensions of meaning (connotation) of the original meaning (denotation). In the case of these examples it is easy to see the connection of the meaning green and the use of 'green'. The meaning in the second group constitutes a metaphor formed on the base of traffic lights. In this way you can say that the meaning of the word green is simply green, that is, it has not changed. Although metaphoric, it is merely an extension of meaning of green, based on one of the uses it has today. However, other uses of green can be interpreted but not at first sight. Example, the church green, the village green

Hogan went slightly green 44 .

The meaning in these examples is another extension of

42 Collins Co-Build English Language Dictionary.

43 Collins Co-Build English Language Dictionary.

44 Collins Co-Build English Language Dictionary. 
meaning formed on the base of a change in the category used, thus forming a metonymy. The change consists in the shift in the way of giving meaning. In the denotative case green conveys meaning with the application of an open dimension of signification to a semantic object, that is, as an adjective. In the new sense and due to the frequent use of the adjective in green grass the adjective was made to convey its meaning, green, in the way expressed with nouns.

The meaning in the last examples, however, cannot be guessed unless you knew the expression. Hogan went green because he was green with rage, that is, because of the emotional state Hogan was in (he was visibly upset and the colour of his complexion changed-only temporarily, it is supposed). Here you have an extension of meaning giving a new sense based on a metaphorical use inserted in the tradition of speaking.

But sometimes there is no transparent explanation in certain uses introduced in the tradition of speaking in a language. In these expressions unless speakers know the expression they will not understand the meaning of it. In the following examples,

Alex has green fingers (British English). Jim has a green thumb (American English)

the meaning of the expressions cannot be explained but historically, that is, referring the expression to the language already performed and constituted in a tradition of speaking. These expressions belong to repeated speech. They mean to be good at gardening 45 . In the same sense you must know what it is all about to interpret the expression,

\section{...green activists.}

In this expression green does not appear as an adjective but a noun, meaning activists particularly involved in the protection of the environment. Sometimes words may exist in the language meaning something disparaging in its form and content, with no connection with the original reality the word was formed in accordance with. The examples

\section{An infant; infantile}

have lost the connection they had with the elements composing them in their origin. Infant is to be referred to its Indo-European origin. The meaning it actually conveys does not match with its form. The word is a combination of a prefix plus the stem of a verb. The verb has disappeared, and the extant prefix in-, is no longer operative in the word, although it is operative in the language. Infant comes from the negative prefix in-plus the Indo-European verb having prompted the Gr. fari or Gr. femi (=to speak), thus meaning «someone who cannot speak yet». These relationships of signification were lost; now the word is an independent one thus conveying clues of meaning with no connection with its origin, etymology or formation.
Vocabulary thus is a set of elements, every one with a particular historical explanation, but this explanation does not necessarily provide us with sufficient reasons for the explanation of its meaning. The case of infant and infantile is illustrative enough to conclude that the etymology or the composition of words and meanings is not the explanation of the meaning of words. It is necessary to know something else in every case. In examples like these, you can see how words can constitute facts of language, facts of evolution, or facts of speech. Denotation and connotation relate to language use thus involving the evolution of the meaning of words in a language or in language use.

Anyway, the analysis of meaning or the analysis of any aspect of the historical language is the analysis of the present state of a tradition. To this respect it is necessary to refer to the words by Ortega y Gasset:

[Words] have a privileged sense, the greatest or authentic one, namely, the one they had when they were created $[\ldots]$ every word originally is the verbal or linguistic reaction before a typical living situation (my translation) ${ }^{46}$.

It is necessary to say that words are not created all of a sudden, but they are created and re-created whenever they are used in speech. The important thing in the analysis of meaning thus is not the form of words but guessing out those conditioners having prompted the speaking subject to select some means of expression in particular (content, included) and not others. Because of this, the analysis of words must be hermeneutics, that is, interpretation, "a systematic founded revelation of a particular content" 47 , or the science of interpretation with the purpose of "determining in which whole the part must be remitted"48.

\section{The Configuration of Speaking}

In order to determine the value of meaning it is necessary to determine the functional language (cf. 5.2) a particular word or expression belongs to. Meaning is given in the activity of speaking and this must be specified in the techniques determining it.

A language is a series of techniques for any possible speech historically determined 49 . In this sense, language is a historical technique in the activity of speaking50. In fact the different languages are nothing but modes in the activity of speaking51. The different modes in the activity of speaking, when they are homogeneous, constitute the different functional languages. Particular languages are not homogeneous and the elements in them keep different types of relationships of signification with one another.

\footnotetext{
46 Ortega y Gasset, 2002, p. 24.

47 Coseriu, 2006, p. 57.

48 Ortega y Gasset, OC, IX, p. 36

49 Coseriu 1988, p. 48.

50 Coseriu 1985, p. 194

51 Coseriu 1985, p. 17
} 


\subsection{The Architecture of the Language}

A technique of speaking insofar as it is a technique, that is, the knowledge required to speak (idiomatic knowledge), has both an external and internal equilibrium. Every language, every technique of speaking, has an architecture, or external equilibrium of speaking, and a structure, or internal equilibrium of speaking. More precisely: any technique of speaking has an architecture and in every part of that architecture it has a structure 52 .

The architecture of the technique of speaking insofar as it represents the external equilibrium of the technique of speaking is the synthesis of idiomatic knowledge, determined, within synchrony, by three sets of differences:

1. diatopic differences, or the differences in the technique of speaking determined with the territory the language is spoken in. The differences originated in this way are called dialects, accents or dialectal accents. For example, the English language is constituted with a large group of dialects, called, roughly speaking, British English, Scottish English, Cokney, American English, Australian English, and South-African English. Something similar happens with all languages. A dialect is a syntopic language.

2. diastratic differences, or the differences in the technique of speaking determined with the different social strata in connection with the disciplines or fields of knowledge proper of those social strata. The differences originated in this way constitute the levels of speech. In this sense you can single out the language of guild corporations: the language of doctors, computer engineers, legal language, etc. These languages do not have geographic definition, since they may have diatopic differences as well. A particular level of speech constitutes a synestratic language; and

3. diaphasic differences, or the differences in the technique of speaking determined with situations and contexts, thus giving birth to the styles of speech. In this sense you can point out formal speech or informal speech, poetic language, etc. These functional languages do not have geographic definition either but they can include regional differences. A particular style of speech constitutes $a$ symphasic language53.

\subsection{The Functional Language}

A uniform and homogeneous technique of speaking is a syntopic, synestratic and symphasic language, thus constituting a functional language. A functional language is a technique of speaking considered in a particular point of space, a level of speech and a style of speech. It is a completely homogenous language, the only language liable to be spoken54. In this way and considering the variety of idiomatic

52 Coseriu 1992, p. 290.

53 Coseriu 1986b, p. 306.

54 Cf. Coseriu 1992, p. 291. knowledge, every speaker knows several functional languages. For example, a particular speaker may know the formal language and informal language in his speech community, the language in his professional field, the language used with his group of friends, the language in his family, and so on.

In some languages there are formal differences separating the different functional languages. For example, in Spanish the use of formal language and informal language, when addressing someone, changes in its form. You may say, ¿Viene $V d$. conmigo? (formal language), instead of the informal use, ¿Vienes tú conmigo?

Standard language or model language 55 is a unitary language, that is, a functional language commonly accepted by speakers of a particular speech community (=a language) as the correct one. It does not usually have dialectal variety but it is determined diaphasically, since it is usually spoken in different styles of speech. In order to determine what a functional language is like, you have to say that a functional language is an ideal model used by speakers. As such it has virtual existence as knowledge.

The architecture of the language relates to the multiple techniques of speaking existing in a historical language, that is, to the different dialects, levels and styles of speech making up a historical language. In the different elements constituting the architecture of the language there is diversity. In the architecture of a language you can find analogous terms (signifiers) with different meanings (signified) 56. For example, in American English when referring to the ground floor you'll say the first floor. In the same way when referring to luggage you'll say baggage. Similarly, to refer to a station where you can fill in petrol, you'll say a gas station but $a$ filling station or a petrol station in British English; to prepare the table for eating you will say to put the table in American English, but to lay the table in British English. That is, you have the same reality, but analogous signifiers and meanings.

In the architecture of the language there are different techniques of speaking with different traditions and thus different norms of the language (cf. $\S 5.5$.). That is, in the architecture of the language there are different functional languages. Historical languages thus constitute a set of functional languages. As a consequence the different techniques of speaking in a historical language must be considered different languages. They must be dealt with and analysed separately.

\subsection{The Structure of the Language}

The technique of speaking constitutes structured knowledge, the idiomatic knowledge of speakers to speak in accordance with the conditions affecting language. Linguistic knowledge as it is structured can be analysed in the different elements constituting it. The structure of the language consists in determining the elements making possible the equilibrium in the technique of speaking, that is, in achieving the only

55 Coseriu 1992, p. 164.

56 Coseriu 1981, pp. 120-121. 
language able to function, the functional language. In the architecture of the language you can find variety of linguistic forms, that is, a particular thing or reality (signified) relates to different words (signifiers); in the structure of a language you can find opposition and solidarity between signifier and signified, that is, different signifiers may relate to one meaning (signified). For example, in English you can have the adjectives

courteous; cultivated; cultured; genteel; polite; refined; well-bred; well-mannered

to relate to one meaning. In this sense they oppose one another: every adjective has its exact meaning as opposing the meaning of the others. 'Courteous', although similar to the meaning of the others, opposes them all. But in their signification as a group, they oppose the following set of adjectives,

barbaric; barbarous; boorish; ill-bred; savage; uncouth.

And in a different manner they oppose as well

clumsy;

and in another one, they oppose

contemptible.

At the same time all these adjectives are to be combined with nouns and expressions denoting human beings. You can say, he is courteous, uncouth, clumsy or contemptible. That is, within the structure of a language you can find relationships of opposition and solidarity.

The distinction between the architecture of the language and the structure of the language is particularly important in the study of meaning. Meaning can change depending on the words used in the different territories, levels of speech and styles of speech.

\subsection{A Technique of Speaking}

A technique of speaking is primarily to be understood as the performance of speech in a speech community, that is, as the usual or normal performances of a homogeneous set of procedures and linguistic units. This technique of speaking is independent insofar as it has usually been performed. At the same time it is objectively functional, that is, distinctive or oppositional. In this sense a technique of speaking is to be distinguished from speech. The technique of speaking underlies speech and thus is different from it. The individual performances of a particular language are to be separated from the technique of speaking, since the technique of speaking of a particular language is implicit in these individual performances, thus manifesting itself in individual performances 57 .

\subsection{Aspects and Levels in the Structure of the Language}

57 Coseriu 1992, p. 293.
With this you can separate different aspects in the activity of speaking in as much as it is structured knowledge within the functional language:

1) first, speech;

2) second, what is usual or, in other words, normal;

3) third, the technique in producing speech;

4) and fourth, what is systematic.

From speech you can abstract, that is, extract, the technique of speaking, that is, idiomatic knowledge, which is both usual and historical (=made in a speech community in history), and oppositional and functional (systematic).

These distinctions and the separation of them in the technique of speaking and the individual performances of speaking (speech), can be made through a double operation of abstraction:

a) abstraction of the individuality, subjectivity, originality and creativity of speaking subjects at the moment of speaking; and

b) abstraction of the variety of performance in a speech community.

That is, the concept of the technique of speaking is nothing representing a concrete object. It is a concept got through abstraction. It has not concrete existence: it merely exists as virtual (since it is knowledge) in the speech of individuals58. In connection with this process of abstraction the technique of speaking can be structured at four levels:

1. speech

2. the norm of the language

3. the system of the language

4. the type of the language59.

Speech is the concrete performance of the technique of speaking, something given in the daily language use in the words of speakers. The norm of the language is the language already performed and constituted in a tradition in the technique of speaking60. It encompasses everything that, in the technique of speaking, not necessarily functional (=distinctive), is socially or traditionally fixed thus constituting common use in the speech community. The system of the language is a set of functional and distinctive oppositions, that is, a set of possibilities. It encompasses everything that, within the sphere of tradition, is at the same time traditional and objectively functional, that is, distinctive. And the type of the language is the set of oppositions and distinctions proper of a language, a set of tendencies to be found as proper and characteristic of a language 61.

The norm of the language relates to language as a social institution. The system of the language relates to the set of distinctive functions, that is, to oppositional structures. The norm of the language is a formalized set of traditional performances: it encompasses what has already been performed. The system of the language, on the contrary, is a

\footnotetext{
58 Cf. Coseriu 1981, pp. 123-130.

59 Coseriu 1992, p. 292.

60 Cf. Coseriu, 1981, p. 126

61 Coseriu 1981, pp. 123-130; Coseriu1992, pp. 293-306.
} 
set of possibilities of performance: it encompasses both what has already been performed and what has not yet been performed, but it is virtually existent, that is possible. It can at any time be created in accordance with the functional rules of the language. And the type of the language is the set of tendencies in a language. It encompasses the types of functions, oppositions and procedures, the types of functional categories and principles of a technique of speaking manifesting themselves at the level of the system of the language62.

The separation of the different levels in the structure of the language is fundamental to the description of language in so far as it is spoken. In order to illustrate this distinction, let us analyse the following examples. Imagine the following pieces of speech

Nobody knows what I went through waiting for the verdict.

No one knows what I experienced when waiting for the verdict.

I was unhappy and miserable waiting for the verdict.

Nobody knows how anxious I was when I waited for the verdict.

I was completely distressful and alone when waiting for the verdict.

Here you have five individual performances of a speech act. They all are correct, coherent and congruent. At the same time they all are adequate, appropriate and opportune. They describe a situation affecting the speaker. If you analyse them, you can say that they constitute different performances of the activity of speaking. In themselves they constitute five speech acts thus belonging to speech. They represent the lowest level in the activity of speaking, since they are concrete acts of speaking.

It you analyse them, you shall see that they all belong to the usual performances of the English language, that is, they belong to the norm of the language. You can see that there are many elements having been previously performed and thus common to all speakers of the speech community we call the English language.

But if you have a closer look, you shall see that you can abstract, that is, separate, the different means of expression they are constituted with, which may be valid for future performances. You can single out elements belonging to the semantic level: the use of words with their corresponding meanings, know, go through, wait, verdict; elements belonging to the morphologic level, the singular, the use of affixes to conjugate verbs, the use of determiners and prepositions, the use of phrasal verbs and verb + particle, etc. You can as well find elements belonging to the syntactic level, the word order, the arrangement of elements; etc. you can single out elements belonging to the phonetic level and elements arranged in such

62 Coseriu 1992, p. 300. a way as to express the meaningful intentional purpose of the individual speaker. That is, in your analysis you select all those elements, which since they are usual and common thus belonging to the norm of the language, can be used as models to form new expressions. At the same time the elements found out in the sentences analysed, keep different relationships of opposition and solidarity. They keep relationships of opposition in words: some are nouns, some verbs, and some adjectives; in the meanings expressed; in the combination of the elements, etc.; and relationships of solidarity: verbs, for example, request a particular type of semantic object to act as the subject or the object of the sentence. This third analysis leads us to find out the functional and distinctive oppositions and solidarities in the different sentences, prompting us conclude that they all belong to the system of the language, the system of possibilities for future performances.

Finally you can speak of the type of the language, that is, the set of functional tendencies proper of this language thus distinguishing it from other languages. In the different examples you can find verb phrases (go through), no explicit expression of the subject with gerunds (when waiting), or the tendency not to mark person distinction in verbs (verbal forms, went, experienced 63 .

A language can only be described and analysed as a functional language 64. A functional language is the only language apt to be spoken. A functional language does not relate to a historical language or the totality of speech of a particular speaker. Functional description and structural description are given only in a functional language, since functional description relates to structured knowledge. Oppositions must be described in the functional language they belong to.

\section{The Configuration of Linguistic Content}

Meaning is present at all levels of idiomatic knowledge (=linguistic competence) 65. Linguistic competence is the universal human activity that individuals as representative of traditions in the technique of speaking perform individually. The activity of speaking has a universal level, going beyond languages, having to do with speaking and the conditions of speaking. It has a particular or historical level, having to do with traditions in the activity of speaking, thus constituting techniques in the activity of speaking, that is, particular languages; and an individual level relating to the individual performances or executions, having do with the particular needs of expression of speakers66.

When speakers speak they will always speak about things with the help of the means of expression of a particular

63 Description is to be made as many times as the terms studied are found in the different structures they are apt to constitute, cf. Coseriu 1981, pp. 118-123. 64 Coseriu 1992, p. 292.

65 Cf. Coseriu 1992, pp. 91-92.

66 Coseriu 1992, p. 74 and ff. 
language, thus creating new senses having to do with particular subjects and topics. Linguistic content is structured in three levels as well.

The first aspect of the configuration of linguistic content is designation. It relates to the universal level of speaking. Designation is the connection established by the particular expression to real things. Designation is not the mere act of pointing at something when speaking. Designation cannot be given but with language.

The second aspect of the configuration of linguistic content is meaning. It relates to the particular level of the activity of speaking, that is, to the particular configuration of facts of experience made with the language67. And finally, the third aspect of the configuration of linguistic content, sense, relates to the individual level of the activity of speaking, the kind of meaning created in every case, by every speaker in particular circumstances with the help of meaning and designation and going beyond meaning and designation 68 .

Meaning has to do with the linguistic description of content. It is structured and belongs to a particular language. Designation belongs to the structuring of things in the real world made by the speaker at the moment of speaking. It has to do with the universal level of speaking. And sense belongs to the individual subject who speaks, not to the particular language.

For example, Sp. traer, E. bring, Fr. apporter, It. apportare and G. bringen 69 constitute different meanings. They can only be defined by means of the relationships of signification functioning as oppositions or solidarities in the languages they belong to. However they can designate the same fact of experience under certain circumstances. Similarly the Sp. escalera, E. staircase, It. scala, and G. Treppe, can designate the same things, but they constitute different systematizations of experience, that is, different meanings.

In the same sense, the fact that the dimension of length in two objects, $\mathrm{A}$ and $\mathrm{B}$, is different from each other may be expressed in one language as "A is larger than B", in another one as "A exceeds B", and another one, simply as, "A is large, $\mathrm{B}$ is small" 70 . The examples of identical designation with different meanings are very numerous, even within a particular language. The following expressions have the same designation (giving one's opinion) but different meanings:

as I see it; in my opinion; personally I believe; personally I feel; it seems to me; I must say that...; don't you think that...; I'd just like to say....; from my point of view; as far as I'm concerned; to my mind; the way I see it...; from where I stand...; if you ask me...; I reckon...; what I reckon is....; I'd say...; I'm convinced that...; I consider...; I'm of the opinion....; its my opinion...; my own view of the matter is...; personally I consider...; I hold the opinion...; its my considered opinion that..; etc.

67 Coseriu 1985a, 247; 1987, 206-208; and 1992, 96

68 Coseriu 1985a, p. 247

69 Example by Coseriu 1985a, p. 220.

70 Example by Coseriu 1985a, 221
Sense is the particular content of a text or a textual unit in so far as this content does not coincide with meaning and designation. The sense of the following syllogism, all human beings are mortal; Peter is a human being; thus Peter is mortal 71, can be interpreted in the following way: "if something is applied of a category, it will necessarily to be applied of all members of that class". Peter in this case is not a mere semantic object but only a member of a class. It would mean the same if the subject was Mary or Andrew. As a matter of fact, this syllogism can have the sense of warning human beings of their mortal condition: remember that you shall die. In poetry this syllogism can be the symbol of human fragility. Questions, answers, the expression of wishes, likes, dislikes, feelings, demands, requests, offers, refusals, giving opinions, encouraging, persuading, complaining, threatening, greetings, etc., are sense categories and thus textual categories.

The distinction of designation, meaning and sense manifests itself in the content of a particular expression. They can be verified in a speech act. A speech act refers to things in the world, that is, it refers to extra-linguistic states of affairs, either physical or mental, with particular idiomatic means of expression, thus conveying a particular textual function (designation). Meaning is the content given in every case by the particular language (the tradition in the technique of speaking, or language as a social institution) used in a speech act; and sense is the particular linguistic content in a particular speech act meant by means of designation and meaning and beyond designation and meaning 72 .

\section{Conclusion}

The same as with language, meaning is nothing but the creation by the individual speaker, who intends to say something coming to him from his inside, thus using words belonging to the speech community. Because of this meaning is all and at the same time creation, historical determination and meaningful intentional purpose.

\section{References}

[1] Aarts, Jan M. G \& Joseph P. Calbert, Metaphor and Non-Metaphor: the Semantics of Adjective Noun Combinations, Tübingen: Max Niemeyer Verlag, 1979.

[2] Bloomfield, Leonard, Language, London: Allen \& Unwin, 1976 (1933).

[3] Chomsky, Noam, Aspects of the Theory of Syntax, The MIT Press, 1965.

[4] Collins-Cobuild English Language Dictionary, 1997, Collins.

[5] Coseriu, Eugenio. 1952, Sistema, norma y habla, Montevideo.

[6] Coseriu, Eugenio. 1977 (1971). Tradición y novedad en la ciencia del lenguaje: estudios de historia de la lingüística. Madrid: Gredos.

71 Example by Coseriu 1985a, 221.

72 Coseriu 1985s, 247. 
[7] Coseriu, E., Principios de semántica estructural, Madrid: Gredos, 1981 (1977).

[8] Coseriu, E., Teoría del lenguaje y lingüística general: cinco estudios, Madrid, Editorial Gredos, (1982) (1962).

[9] Coseriu, E., El hombre y su lenguaje. Madrid, Editorial Gredos, 1985a (1977).

[10] Coseriu, Eugenio. 1985b. "Linguistic Competence: What is it Really?" The Modern Language Review, vol , XXV-XXXV.

[11] Coseriu, E., Introducción a la lingüística, Madrid: Editorial Gredos, 1986a.

[12] Coseriu, E., Lecciones de lingüística general, Madrid: Editorial Gredos, 1986b.

[13] Coseriu, E., Gramática, semántica, universales. Estudios de gramática funcional, Madrid: Gredos, 1987 (1978).

[14] Coseriu, E., Sincronía, diacronía e historia: el problema del cambio lingüístico, Madrid: Gredos, 1988 (1956).

[15] Coseriu, Eugenio. 1990. "Semántica estructural y semántica cognitiva". Homenaje al Profesor Francisco Marsá/Jornadas de Filología. Colecció homenatges. Universidad de Barcelona: 239-282.

[16] Coseriu, E., Competencia lingüística: elementos de la teoría del hablar, Madrid, Editorial Gredos, 1992 (1988).

[17] Coseriu, E. y Ó. Loureda: Lenguaje y discurso, Pamplona, Eunsa, 2006.

[18] Coseriu, E., Lingüística del texto. Introducción a la hermenéutica del sentido, Arco/Libros, 2007 (1973).

[19] Dik, Simon C., Functional Grammar. Amsterdam: North-Holland, 1978, Spanish translation, 1981.

[20] Geckeler, Horst, Semántica estructural y teoría del campo léxico, Madrid: Gredos, 1976 (1971).

[21] Geckeler, Horst, "Structural Semantics". H J Eikmeyer \& H Reiser, eds. Words, Worlds, and Contexts: New Approaches in World Semantics, Berlin \& New York: Walter de Gruyter, 1981: 381-413.

[22] Longman Dictionary of Contemporary English, Longman.

[23] Longman Language Activator, Longman, 1988.

[24] Lyons, John, Semántica. Barcelona: Teide, 1980 (1977).

[25] Martínez del Castillo, Jesús, An Open Dimension of Meaning: A Semantic Study of Adjectives and Their Combinations. Universidad de Almería, 1997.
[26] Martínez del Castillo, Jesús, La intelección, el significado, los adjetivos, Universidad de Almería, 1999.

[27] Martínez del Castillo, Jesús, Significado y conocimiento: la significación de los adjetivos subjetivos. Granada Lingvistica,

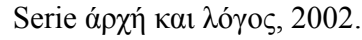

[28] Martínez del Castillo, Jesús, La lingüística del decir. El logos semántico y el logos apofántico, Granada: Granada Lingvistica,

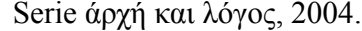

[29] Martínez del Castillo, Jesús, «Hablar, decir y conocer: el acto lingüístico», Oralia, 11 (2008): 375-97.

[30] Martínez del Castillo, Jesús: «El logos semántico y el logos apofántico» Enérgeia I, Online-Zeitschrift für Sprachwissenchaft, Sprachphilosophie und Sprachwissenschaftsgeschichte. 2009: 50-80.

[31] Martínez del Castillo, Jesús, ed., Eugenio Coseriu (1921-2002) en los comienzos del siglo XXI, 2 vols. in Analecta Malacitana, Anejos/86, 2012.

[32] Martínez del Castillo, Jesús, English Semantics and Lexicology, Universidad de Almería, 2013.

[33] Martínez del Castillo, Modes of Thinking, Language and Liinguistics, in Analecta Malacitana, 2013.

[34] McArthur, Tom, ed., Longman Lexicon of Contemporary English, Longman, 1981.

[35] McArthur, Tom, ed., The Oxford Companion to the English Language, Oxford, New Your: Oxford University Press, 1992.

[36] Ortega y Gasset, José, ¿Qué es conocimiento?, Alianza Editorial, 1992 (1984).

[37] Ortega y Gasset, José, El hombre y la gente, Alianza Editorial, 2001 (1957).

[38] Ortega y Gasset, José, Meditación de la técnica y otros ensayos de ciencia y filosofía, Alianza Editorial, 2002 (1993).

[39] Ortega y Gasset, José, Obras completas, IX, Taurus, 2009.

[40] Pottier, Bernard, Lingüística general: teoría y descripción. Madrid: Gredos, 1976 (1974)

[41] Saussure, Ferdinand de., Curso de lingüística general, Buenos Aires: Losada, 1974 (1916).

[42] Whorf, Benjamin Lee, Language, Thought and Reality. Selected Writings of Benjamin Lee Whorf, Lewis Carrol, ed., Cambridge, Massachusetts: Massachusetts Institute of Technology, 1956. 